\title{
ОСОБЛИВОСТІ ПСИХОЛОГІЧНОЇ ГОТОВНОСТІ УЧИТЕЛІВ ПОЧАТКОВИХ КЛАСІВ ДО ПРОФЕСІЙНОЇ ДІЯЛЬНОСТІ В УМОВАХ РЕАЛІЗАЦІЇ КОНЦЕПЦЇ̈ «НОВА УКРАЇНСЬКА ШКОЛА»
}

\author{
Тетяна Мостова \\ аспірантка кафедри педагогіки та психології освітньої діяльності \\ Запорізький національний університет \\ 69600, Україна, м. Запоріжжя, вул. Жуковського, 66 \\ tanyasynytsyacorr0201@gmail.com, https://orcid.org/0000-0002-6555-0367
}

\begin{abstract}
Анотація
Статтю присвячено емпіричному виявленню особливостей психологічної готовності учителів початкових класів до професійної діяльності в умовах реалізації Концепції «Нова українська школа». Методи дослідження: застосовано теоретичні (аналіз, синтез, класифікація, узагальнення, абстрагування, конкретизація) й емпіричні (опитування) методи; методи інтерпретації даних. В опитуванні взяли участь 46 вчителів початкових класів різних закладів освіти Запорізької області. Респонденти є працівниками закладів загальної середньої освіти віком від 25 до 65 років. В статті подано результати опитування учителів початкових класів щодо психологічних особливостей професійної діяльності в умовах реалізації Концепції «Нова українська школа». За результатами проведеного опитування отримано такі дані: 1) вчителі зауважують про такі психологічні бар'єри, як нестача внутрішніх ресурсів до змін і невпевненість; 2) у процесі опитування виявлено, що значна частина респондентів має нестабільний психоемоційний стан, внаслідок суттєвого зростання вимог до професійної діяльності. Отримані результати опитування дозволяють стверджувати про необхідність надання учителям початкових класів психологічної допомоги в аспекті усвідомлення та прийняття ними нових вимог до їх професійної діяльності, що, в свою чергу, надасть змогу мінімізувати фрустраційний вплив на особистість та попередити деструктивні психоемоційні стани загалом. Також результати дослідження вказують на можливу тенденцію до професійного та емоційного вигорання. Хоча й педагоги стверджують про високий рівень власної готовності до нового формату діяльності відповідно Концепції НУШ, проте їхній психоемоційний стан вказує на протилежне. Отже, одержані результати, засвідчують про наявність суперечностей, які вказують на те, що вчителі психологічно не сприймають швидкий темп реформування і появу інновацій у професійній діяльності.
\end{abstract}

Ключові слова: учитель початкових класів, професійна діяльність, «Нова українська школа», готовність до професійної діяльності, психологічна готовність, інновації, стрес, психологічні бар'єри, рефлексія.

\section{Вступ}

32017 року і досі продовжується активне впровадження реформ в галузі освіти України. Відповідно до вимог Концепції реалізації державної політики в сфері реформування загальної середньої освіти «Нова українська школа» на період до 2029 року, що схвалено розпорядженням Кабінету Міністрів України від 14.12.2016 р. № 988 (Концепція реалізації державної політики у сфері реформування загальної середньої освіти “Нова українська 
школа” на період до 2029 р., 2016), важливим є забезпечення індивідуально-особистісного і професійно-діяльнісного самовдосконалення педагогів початкової школи завдяки активізації їхньої базової освіти, набутого професійного та життєвого досвіду. Для більшості вчителів відповідати вимогам Концепції досить складно, адже для ії реалізації змінюються умови не тільки до професійного, а й до особистісного розвитку вчителя. Також важливим є питання психологічної готовності учителя початкових класів до постійних змін у професійній діяльності, які сприяють виникненню стресу та його наслідків - зниження мотивованості, професійна фрустрованість та емоційне вигорання, депресивні стани.

Актуальність проблеми формування психологічної готовності педагогів до роботи в новій українській школі (НУШ) зумовлена кількома чинниками. По-перше, реформа освіти це системна інновація, яка, як і будь-які інші інновації, призводить, передусім, до змін психологічного стану педагогів, впливає на ступінь їхньої впевненості в собі. Так, за результатами онлайн-опитування вчителів початкових класів закладів загальної середньої освіти області (2018р.), готовими до роботи за новим Державним стандартом початкової загальної освіти вважала себе лише третина респондентів. По-друге, переважна більшість вчителів, які працюють у початкових класах - це спеціалісти, які мають значний стаж роботи. Серед вчителів, які у 2018/2019 навчальному році працювали у 1 класі, половина (58\%) мала стаж роботи понад 20 років; четверта частина $(25,5 \%)$ - вчителі зі стажем від 10 до 20 років. В цьому є сильні (значний досвід роботи, готовність до самостійності) та слабкі (труднощі у сприйнятті інновацій, професійне вигорання тощо) сторони. На практиці це може призвести до того, що впровадження нової ідеї, проєкту або технології може наштовхнутися на різні перешкоди, або так звані антиінноваційні бар'єри (Марухіна, 2019).

В сучасній психології психологічна готовність розглядається як істотна передумова будь-якої цілеспрямованої діяльності, іiі регуляції, стійкості та ефективності. В рамках функціонального підходу, психологічна готовність трактується як певний стан психічних функцій, що забезпечує високий рівень досягнень при виконанні того чи іншого виду діяльності (Вітюк, 2016; Дичківська, 2004; Гура \& Рома, 2019). В контексті особистісного підходу психологічну готовність розглядають як результат підготовки (підготовленості) до певної діяльності - як стійке, багатостороннє, ієрархічне утворення особистості, що містить компоненти (мотиваційний, когнітивний, операційний тощо), адекватні вимогам, змісту та умовам діяльності, що у сукупності й дозволяють суб'єкту більш або менш успішно здійснювати діяльність (Лунячек, 2019; Яценко, Кмит \& Олексієнко, 2002).

Розгляд наукової літератури з питань готовності педагогів до змін в умовах реалізації Концепції «Нова українська школа» свідчить, що теоретичні основи готовності педагогів до інноваційної діяльності висвітлено у працях вітчизняних і зарубіжних науковців (Дичківська, 2004). Аналіз наукових джерел 3 педагогічної інноватики виявляє, що успішність інноваційної діяльності багато в чому залежить від психологічної готовності педагога до сприйняття та реалізації нововведень (Вітюк, 2016; Лунячек, 2019).

Спроби пояснити природу неефективних дій і деструктивних тенденцій у педагогічній діяльності здійснювались у багатьох психологічних дослідженнях. Їх чинники пов'язувались із соціальними аспектами професії вчителя, іï низькою престижністю, порушеннями процесу професійного і особистісного розвитку педагога (Остополець, 2000), стресонасиченістю, конфліктогенністю та фрустраційністю педагогічної діяльності (Тукаев, Паламарь, Вашека \& Мишиев, 2020; Чебыкин, 1995), деструктивністю внутрішньоособистісного захисного конфлікту педагога (Яценко, 2002), проблемами і труднощами його професійної адаптації, 
несформованістю адекватних засобів педагогічної діяльності, спілкування й встановлення міжособових стосунків (Кмит \& Олексієнко, 2002), низькою розвиненістю професійного мислення (Grinyova \& Rezvan, 2016), невідповідністю ціннісно-смислової системи особистості вчителя вимогам професії (Вітюк, 2016).

Отже, метою дослідження $є$ емпіричне виявлення особливостей психологічної готовності учителів початкових класів до професійної діяльності в умовах реалізації Концепції «Нова українська школа». Завдання дослідження: 1) розглянути поняття «психологічний бар'єр», «професійна фрустрованість»; 2) проаналізувати результати опитування учителів початкових класів щодо усвідомлення ними психологічних особливостей їхньої готовності до професійної діяльності в умовах НУШ.

\section{Методи дослідження}

В дослідженні застосовано: теоретичні (аналіз, синтез, класифікація, узагальнення, абстрагування, конкретизація) й емпіричні (опитування) методи; методи інтерпретації даних.

\section{Результати та дискусії}

В процесі впровадження Концепції, у якій чітко декларується, що НУШ має готувати особистість, громадянина і фахівця, тому й особистість учителя початкових класів має відповідати новим стандартам. Це ті осі координат, які формуватимуть простір нової школи: індивідуально-психологічну, суспільно-політичну та соціально-економічну. За прогнозами експертів, найбільш затребуваними на ринку праці будуть вміння навчатися впродовж життя, критично мислити, ставити мету і досягати іï, працювати в команді, спілкуватися в культурному середовищі (Концепція реалізації державної політики у сфері реформування загальної середньої освіти "Нова українська школа" на період до 2029 р., 2016).

В Державному стандарті початкової освіти серед обов'язкових результатів навчання визначено не лише вміння і знання, але й життєво необхідні компетентності, що дають можливість учневі бути спроможним до навчання в будь-якій країні світу. Виокремлено й основні індивідуально-особистісні та професійно-діяльнісні якості учителя, яких він має набути для успішного виконання стратегічної мети й завдань реформування початкової освіти (Дичківська, 2004). Для повноцінної роботи, за вимогами НУШ, учитель повинен постійно розвивати й актуалізувати свої базові навички. Базовими компетентностями вчителя початкових класів НУШ є такі: 1) професійно-педагогічна - учитель має володіти інноваційними відомостями у таких сферах, як педагогіка, психологія, а також володіти здатністю до педагогічної рефлексії; 2) соціально-громадянська - учитель повинен розуміти сутність громадянського суспільства; 3) загальнокультурна - учитель початкових класів має розуміти твори мистецтва, самостійно виявляти ідеї, досвід і почуття засобами мистецтва; 4) мовно-комунікативна - педагог має володіти системними знаннями про норми i типи педагогічного спілкування в процесі організації колективної та індивідуальної діяльності; 5) психологічно-фасилітативна - учитель має усвідомлювати цінність фізичного, психічного і морального здоров'я дитини; 6) підприємницька - педагог має пропонувати нові ініціативи та реалізувати їх; 7) інформаційно-цифрова - учитель має орієнтуватися в інформаційному просторі (Гриневич, 2019). Для того, щоб ефективно реалізувати усі визначені Державним стандартом компетенції у професійну діяльність, вчитель має бути готовим психологічно сприймати ту чи іншу системну складову, а також навчитись виявляти їх в особистісних якостях. 3 точки зору психології, такі вимоги до особистості вчителя потребують 
переформатування системи сприйняття загалом і швидкість необхідних змін досить часто зумовлює перенапруження емоційного, психологічного та фізіологічного стану.

Психологічна готовність до нововведень - це цілісний психологічний феномен, що поєднує такі компоненти: мотиваційний, когнітивний, операційний, особистісний. Основним $\epsilon$ мотиваційний. Саме вчитель $є$ однією зі складових формули НУШ, адже агентом змін може стати лише умотивований вчитель, який має свободу творчості й розвивається професійно.

Для сучасних освітян є викликом: постійне ускладнення змісту освіти, гарантування високого рівня освітніх стандартів; ускладнення проблеми виховання; безперервне оволодіння прогресивними технологіями навчання та виховання; розв'язання складних професійно-педагогічних проблем, які вимагають інтеграції знань, практичних умінь i навичок; робота в єдиному інформаційному середовищі, що передбачає раціональне використання інформаційних технологій у навчально-виховному процесі (Вітюк, 2016).

Тому, впровадження Концепції НУШ часто наштовхується на різні перешкоди (бар'єри), і, передусім, внутрішні бар'єри - психологічні (особистісні), які приховують глибинні особистісно-професійні проблеми учителів (Лунячек, 2019).

Відповідно до положень сучасної психологічної науки, психологічні бар'єри - це психічні стани, що виявляються у пасивності педагога, яка заважає здійснювати інноваційну діяльність (Дичківська, 2004). Психологічні бар'єри виникають за необхідності вийти за межі звичних способів розв'язання професійного завдання, надати переваг іншій точці зору. Вони постають як внутрішні перепони (відсутність бажання щось змінювати, страх, невпевненість тощо), що заважають людині виконувати певну дію. Особистісний бар'єр є соціальнопсихологічним утворенням, параметри якого змінюються у просторі й часі на різних етапах нововведення, в різних організаціях, у різних категорій працівників.

Психологічні бар'єри існують як: 1) форма прояву соціально-психологічного клімату колективу в умовах інновацій у вигляді негативних психічних станів працівників, зумовлених нововведенням; 2) сукупність дій, суджень, понять, очікувань і емоційних переживань працівників, у яких усвідомлено чи неусвідомлено, приховано чи неприховано виявляються негативні психічні стани.

Зміни й новизна завжди викликали у людей тривогу і страх. Нерідко інновації, які руйнували усталений спосіб життя, звички людей, зумовлювали хворобливі реакції. Одним із видів негативної психічної реакції на інновації є фрустрація (Чебыкин, 1995).

Запровадження змін у професійній діяльності учителя може провокувати такий психічний стан, як фрустрація, що характеризується об'єктивно неподоланними (або такими, що так сприймаються суб'єктом) труднощами в розв'язанні значущих для людини завдань. Такий стан може бути спричинений надто швидким, надто частим або перманентним впровадженням інновації. Подібні наслідки можуть мати і впровадження масштабних (системних) та безальтернативних інновацій (Grinyova \& Rezvan, 2016).

Опір нововведенням може поставати як пряма відмова від участі в інноваційній діяльності, імітація активності з одночасною демонстрацією того, що нововведення не дає позитивних результатів. Часто на шляху нового стає консервативний до новацій досвід роботи. Щоб подолати ці бар'єри педагог нерідко повинен не лише осмислити, обгрунтувати інноваційну ідею, а й виявляти громадянську мужність під час іiі реалізації (Вітюк, 2016).

Часто буває так, що вчитель не досягає поставлених цілей, вибирає таку форму спілкування, яка не відповідає професійним етичним вимогам. Також не всі учні виявляють бажання отримувати знання і пізнавати. Їх важко навчити управляти власною діяльністю. I 
це, в свою чергу, викликає в учителів усвідомлення того, що вони не можуть досягнути бажаних результатів, бути успішними, викликає незадоволення, негативні емоційні стани, зневірення у професійній спроможності, та, як наслідок - у них формується синдром професійного вигоряння, що призводить до професійної фрустрованості вчителя (Тукаев, Паламарь, Вашека \& Мишиев, 2020). Саме нові умови, що створюються у ході активного реформуванням початкової освіти, створюють підгрунтя для дослідження психологічних особливостей професійної діяльності та безпосередньо емоційний стан учителів початкових класів, які вимушені постійно та швидко пристосовуватись до професійних змін.

Згідно результатів сучасних досліджень, вітчизняні педагоги мають низький рівень командної співпраці. Найменше в українських школах практикуються такі форми співпраці вчителів, як навчання спільно з іншими вчителями в одному класі, залучення до спільної роботи в різних класах i вікових групах (наприклад, спільних проєктах), командне спостереження за роботою інших учителів з метою надання зворотного зв'язку. Низький рівень командної співпраці вчителів негативно впливає на командну співпрацю учнів та забезпечення міждисциплінарних зв'язків між різними предметами під час реалізації освітнього процесу. Серед методів викладання переважає репродуктивне навчання. Встановлено, що кожен третій український учитель почувається емоційно виснаженим, кожен п’ятий - фізично виснаженим, роздратованим або злим (Гура \& Рома, 2019).

Для визначення психологічних потреб вітчизняних вчителів початкової школи на базі Запорізького обласного інституту післядипломної педагогічної освіти в червні 2020 року проводилося опитування щодо усвідомлення педагогами психологічних особливостей їх професійної діяльності в умовах освітніх реформ, зокрема, впровадження НУШ. Для цього був розроблений авторський опитувальник, що містив відкриті та закриті запитання, шкали оцінювання. В опитуванні взяли участь 46 вчителів початкових класів різних закладів освіти Запорізької області. Більшість респондентів є працівниками закладів загальної середньої освіти - 51,1\%; навчально-виховних комплексів - 31,1\%; гімназій - 8,9\%; ліцею, інтернату по 2,2\%. 3 них: 68,9\% - мають більше 20 років педагогічного стажу; 13,3\% - від 10 до 15 років; 6,7\% - від 3 до 10 років і 6,7\% - від 15 до 20 років; 4,4\% - від 1 до 3 років стажу. Вік вчителів варіюється від 25 до 65 років.

Аналіз отриманих даних свідчить про те, що в умовах постійних освітніх реформ, які змінюються одна за одною, учителі не завжди здатні опанувати нові знання, виробити нові професійні вміння та усвідомити необхідність змін. На нашу думку, важливим показником проведеного опитування є такий. Вчителі зауважують про те, що такі психологічні бар'єри, як нестача внутрішніх ресурсів до змін (40\%) та невпевненість $(37,8 \%)$, заважають їм швидко змінювати свою педагогічну діяльність відповідно до нових вимог НУШ. Варто звернути увагу й на те, що існує певна невідповідність, суперечності у відповідях. Так, на запитання «Які труднощі виникають у Вас у процесі реалізації Концепції НУШ?» - 53,3\% вчителів початкових класів визначають проблеми з методичним забезпеченням, 44,4\% - нестабільним психоемоційним станом внаслідок суттєвого зростання вимог; 42,2\% - погіршенням стану здоров'я внаслідок втоми. Водночас, допомоги не потребує 35,2\% вчителів і 86,7\% визначили високим свій рівень готовності до нового формату діяльності відповідно Концепції НУШ. Виявлені суперечності можуть свідчити про те, що вчителі психологічно не сприймають швидкий темп реформування і появу інновацій у професійній діяльності. 


\section{Висновки}

Отже, одержані результати засвідчують, що українським учителям початкових класів важко пристосовуватись до нововведень. Аналіз результатів опитування дозволив встановити, що хоча педагоги й стверджують про високий рівень власної готовності до нового формату діяльності відповідно Концепції НУШ, проте їхній психоемоційний стан вказує на протилежне. Високий показник відмови вчителів від допомоги може вказувати на неусвідомленість своїх потреб або на внутрішньоособистісний конфлікт. Наявність втоми, нестабільний психоемоційний стан учителів спільно з високим рівнем готовності до нового формату діяльності згідно Концепції НУШ підтверджує тенденцію до їхнього емоційного і професійного вигорання, що може призвести до появи депресивних станів, професійної деформації та фрустрованості.

Перспективи подальших досліджень вбачаємо в розробці тренінгової програми, яка сприятиме профілактиці у вчителів початкових класів таких психологічних явищ, як професійна фрустрованість, вигорання і стрес в умовах реформування вітчизняної освіти.

\section{Література}

1. Гура, Т.С., \& Рома, О.Ю. (2019). Підготовка вчителів початкових класів Запорізької області до впровадження ігрових методів навчання: від діагностики до розвитку ігрової компетентності. Запоріжжя : ФОП К.С. Советнікова.

2. Вітюк, В. (2016). Професійний розвиток педагогів в умовах інноваційного освітнього середовища післядипломної освіти регіону. Педагогічний пошук, 1(89), 3-6.

3. Дичківська, I. (2004). Інновачійні педагогічні технології. Київ : Академвидав.

4. Гриневич, Л. (2019). План впровадження реформи загальної середньої освіти «Нова украӥнська школа» на період до 2029 року.

Режим доступу: https://mon.gov.ua/storage/app/media/zagalna\%20serednya/nova-ukrainskashkolacompressed.pdf

5. Концепція реалізації державної політики у сфері реформування загальної середньої освіти "Нова українська школа" на період до 2029 року / схвалено розпорядженням Кабінету Міністрів України від 14 грудня 2016 p. №988-p. Режим доступу: https://zakon.rada.gov.ua/laws/show/994_975

6. Лунячек, В. (2019). Нова українська школа: практична реалізація. Режим доступу: https://osvita.ua/school/reform/53666

7. Марухина, I. (2019). Основні завдання та зміст діяльності спеціаліста психологічної служби в умовах упровадження Нової украӥнської школи. Суми : НВВ КЗ СОІППО.

8. Остополець, I. (2000). До проблеми вивчення стану фрустрації вчителів в їх професійній діяльності. Психологія: збірник наукових пращь, 2(9), (Частина 2), 287-290.

9. Тукаев, С., Паламарь, Б., Вашека, Т., \& Мишиев, В. (2020). Синдром эмоционального выгорания. Психофизиологические аспекты. Международный научно-практический журнал «Психиатрия, психотерапия и клиническая психология», 11(4), 791-801.

10. Чебыкин, А.Я. (1995). Проблема эмоциональной устойчивости. (Монография). Одесса : Южноукраинский педагогический университет им. К.Д. Ушинского.

11. Яценко, Т., Кмит, Я., \& Олексієнко, Б. (2002). Активне соціально-психологічне навчання: теорія, процес, практика. Хмельницький : Вид-во НАПВУ.

12. Grinyova, V., \& Rezvan, O. (2016). Modernization of primary school teachers' training: from knowledge to competence approach. Advanced Education, 6, 111-114. https://doi.org/10.20535/2410-8286.85955

13. Safdari S., \& Maftoon, P. (2017). The development of motivation research in educational psychology: the transition from early theories to self-related approaches. Advanced Education, 7, 95-101. https://doi.org/10.20535/2410-8286.93906 


\section{References}

1. Hura, T.Ie., \& Roma, O.Iu. (2019). Pidhotovka vchyteliv pochatkovykh klasiv Zaporizkoi oblasti do vprovadzhennia ihrovykh metodiv navchannia: vid diahnostyky do rozvytku ihrovoi kompetentnosti [Training of primary school teachers of Zaporizhia region for the introduction of game teaching methods: from diagnostics to the development of game competence]. Zaporizhzhia : FOP K.S. Sovetnikova [in Ukrainian].

2. Vityuk, V. (2016). Profesiynyy rozvytok pedahohiv v umovakh innovatsiynoho osvitnjoho seredovyshcha pislyadyplomnoyi osvity rehionu [Professional development of teachers in the conditions of innovative educational environment of postgraduate education of the region]. Pedahohichnyy poshuk - Pedagogical Search, 1(89), 3-6 [in Ukrainian].

3. Dychkivska, I. (2004). Innovatsiini pedahohichni tekhnolohii [Innovative pedagogical technologies]. Kyiv : Akademvydav [in Ukrainian].

4. Hrynevych, L. (2019). Plan vprovadzhennia reformy zahalnoi serednoi osvity "Nova ukrainska shkola" na period do 2029 roku [The plan to implement the reform of general secondary education "New Ukrainian School" for the period up to 2029]. Retrieved from https://mon.gov.ua/storage/app/media/zagalna\%20serednya/nova-ukrainskashkolacompressed.pdf [in Ukrainian].

5. Kontseptsiia realizatsii derzhavnoi polityky u sferi reformuvannia zahalnoi serednoi osvity "Nova ukrainska shkola" na period do 2029 roku [The concept of implementation of state policy in the field of reforming general secondary education "New Ukrainian School" for the period up to 2029]. Approved by the order of the Cabinet of Ministers of Ukraine dated 14, December, 2016 №988-r. Retrieved from https://zakon.rada.gov.ua/laws/show/994_975 [in Ukrainian].

6. Luniachek, V. (2019). Nova ukrainska shkola: praktychna realizatsiia [New Ukrainian school: practical implementation]. Retrieved from https://osvita.ua/school/reform/53666 [in Ukrainian].

7. Marukhyna, I. (2019). Osnovni zavdannia ta zmist diialnosti spetsialista psykholohichnoi sluzhby $v$ umovakh uprovadzhennia Novoi ukrainskoi shkoly [The main tasks and content of the psychological service specialist in the conditions of introduction of the New Ukrainian school]. Sumy : NVV KZ SOIPPO [in Ukrainian].

8. Ostopolets, I. (2000). Do problemy vyvchennia stanu frustratsii vchyteliv v yikh profesiinii diialnosti [To the problem of studying the state of frustration of teachers in their professional activities]. Psykholohiia: Zbirnyk naukovykh prats - Psychology: Collection of scientific works, 2(9), (Part 2), 287-290 [in Ukrainian].

9. Tukayev, S., Palamar, B., Vasheka, T., \& Mishiyev, V. (2020). Sindrom emotsional'nogo vygoraniya. Psikhofiziologicheskiye aspekty [Burnout syndrome. Psychophysiological aspects]. Mezhdunarodnyy nauchno-prakticheskiy zhurnal "Psikhiatriya, psikhoterapiya i klinicheskaya psikhologiya" - International scientific and practical journal "Psychiatry, psychotherapy and clinical psychology”, 11(4), 791-801 [in Russian].

10. Chebykin, A.Ya. (1995). Problema emotsionalnoy ustoychivosti [The problem of emotional stability]. Odessa : Yuzhnoukrainskiy pedagogicheskiy universitet im. K.D. Ushinskogo [in Russian].

11. Yatsenko, T., Kmyt, Ya., \& Oleksiyenko, B. (2002). Aktyvne sotsialno-psykholohichne navchannya: teoriya, protses, praktyka [Active socio-psychological learning: theory, process, practice]. Khmelnyts'kyy : Vyd-vo NAPVU [in Ukrainian].

12. Grinyova, V., \& Rezvan, O. (2016). Modernization of primary school teachers' training: from knowledge to competence approach. Advanced Education, 6, 111-114. https://doi.org/10.20535/2410-8286.85955

13. Safdari S., \& Maftoon, P. (2017). The development of motivation research in educational psychology: the transition from early theories to self-related approaches. Advanced Education, 7, 95-101. https://doi.org/10.20535/2410-8286.93906 


\title{
FEATURES OF PSYCHOLOGICAL READINESS AMONG PRIMARY SCHOOL TEACHERS TO THE PROFESSION UNDER IMPLEMENTATION OF "NEW UKRAINIAN SCHOOL" CONCEPT \\ Tetyana Mostova \\ Postgraduate student of the Department of Psychology and Pedagogy Educational Activities \\ Zaporizhzhya National University \\ 66, Zhukovsky Str., Zaporizhia, Ukraine, 69600 \\ tanyasynytsyacorr0201@gmail.com, https://orcid.org/0000-0002-6555-0367
}

\begin{abstract}
The article focuses on the empirical determination of the peculiarities of the psychological readiness among primary school teachers for professional activity in the context of the implementation of the "New Ukrainian School" Concept. Research methods: The research uses theoretical (analysis, synthesis, classification, generalization, abstraction, specification) and empirical (survey) methods, methods of data interpretation. 46 primary school teachers from various educational institutions of Zaporizhia region took part in the survey. Respondents are the employees of general secondary education institutions, aged from 25 to 65 . The article presents the results of this survey among primary school teachers on the psychological characteristics of professional activity in the implementation of the Concept "New Ukrainian School". According to the results of the survey, the following data were obtained: 1) the teachers note that such psychological barriers as lack of internal resources for change and uncertainty; 2) in the course of the survey we found out that a significant proportion of respondents have an unstable psycho-emotional state, due to a significant increase in the requirements for professional activity. The results of the survey suggest the need to provide primary school teachers with psychological assistance in terms of awareness and acceptance of new requirements for their professional activities, which in its turn will minimize the frustrating impact on the individual and prevent destructive psycho-emotional states in general. Also, the results of the study indicate a possible tendency to professional and emotional burnout. Thus, the obtained results indicate the presence of contradictions, which means that teachers do not psychologically perceive the rapid pace of reform and emergence of innovation in professional activities.
\end{abstract}

Keywords: primary school teacher, professional activity, "New Ukrainian School", readiness for professional activity, psychological readiness, innovations, stress, psychological barriers, reflection.

Подано 26.12.2020

Рекомендовано до друку 26.05.2021 